\title{
Effects of Learning Cycle Model in Preschool Kids Learning of the Growth of Plant
}

\author{
Hakan Türkmen ${ }^{*}$ \\ Ege University, Faculty of Education, Izmir, Turkey
}

Damla Dilara Topkaç

Ege University, Institute of Social Sciences, Izmir, Turkey

\begin{tabular}{|c|c|}
\hline Article history & \multirow{6}{*}{$\begin{array}{l}\text { There has been a movement nationally over decades to integrate } \\
\text { technology and modern learning models into our school curriculums. One } \\
\text { of the modern teaching models is Learning Cycle, a totally different way } \\
\text { of teaching science which comes from students' experiences, rather than } \\
\text { through other learning methods relying on the textbook, which is } \\
\text { generally being used in Turkey. Every student should acquire the basic } \\
\text { knowledge, skills, behaviors, and habits and be prepared for the next } \\
\text { education level parallel to his/her interests and skills. Thus starting } \\
\text { preschool to high school students should be taught with modern teaching } \\
\text { models because, in the information and technology age, children should } \\
\text { be raised curious, thinker, researcher and problem solver. The purpose of } \\
\text { study is to examine how effective learning cycle model in pre-school } \\
\text { students learning on growth of plant and their opinions about the lesson. } \\
\text { In this study, convenience sampling was used. } 25 \text { preschool school } \\
\text { students aging } 6 \text { years selected from rural area in İzmir. Single-grouped } \\
\text { experimental designed has been used in the study. Data have been } \\
\text { collected by using qualitative research method and data collection process } \\
\text { took four weeks. Gathered data have been turned to points (mark, score) } \\
\text { and evaluated by frequency analysis. According to the results, students } \\
\text { have reached the science concept, germination. Most of the students had } \\
\text { fun and learned, and also felt like scientist. }\end{array}$} \\
\hline & \\
\hline $\begin{array}{l}\text { Received in revised form: } \\
18.10 .2015\end{array}$ & \\
\hline $\begin{array}{l}\text { Accepted: } \\
19.10 .2015\end{array}$ & \\
\hline Key r & \\
\hline ichool & \\
\hline
\end{tabular}

\section{Introduction}

In 21th century people using scientific knowledge in daily life have privilege to succeed in society, because they need knowledge to understand what is going on in their country and around the World and have opportunities to solve society problems. We scientifically call such people literate in education. To raise scientifically literate people the only and the most effective way is to educate via student-centered teaching models in schools (Soylu, 2004). In recent years, there have been radical changes in many countries' education system due to the rapid changes in science and technology. As a result, all countries have made changes in their education system in order to raise individuals who can search, investigate, solve problems, apply the technics that they learn when they face problems in daily life and. To gain this learning perceptive we have to start with preschool students

\footnotetext{
*Correspondence: hakan.turkmen@ege.edu.tr
} 
(around 3-6 years old) in formal education system. These kids are real scientists because they learn about the world by observing and experimenting. By preschool time, they learn through play at home or in society. In preschool, students should learn through play with their toys in the same ways, with the guidance of their teachers. Most preschool students are not ready to understand and keep more than one concept in their heads at a time (Barnett, 2003; Coolahan et all, 2000; Vernadakis et all, 2005).

One of useful teaching model is Learning Cycle to educate our students to become literature people (Al khawaldeh, 2013; Ateş, 2005a-b; Marek, 2008; Marek \& Cavallo, 1997; Marek, Eubanks \& Gallaher, 1990; Nuhoğlu, 2006; Ören \& Tezcan, 2008; Settlage, 2000; Türkmen, 2006). Learning Cycle model was well established within Science Curriculum Improvement Study program, being based on research about how children learn and how they develop reasoning skills, based upon the Paget's cognitive development theory by Robert Karplus and Herbert D. Their (Lawson, Abraham, \& Renner, 1989). They declared that Learning Cycle was written in 3 phases, Exploration, Concept Development and Concept Application, upon Piaget's views in the beginning of studies (Ayas, 1995). Latter years, Concept Development phase's name has been changed as Term Introduction (Marek \& Cavallo, 1997). First phase is Exploration, consisting of hands-on activity or field experience in which students gather and record data from their observations and measurements. For these activities students should be grouped. Teacher encourages students to learn through their own experience. For that purpose Teacher is in a passive role and only gives the instruction of the experiment or activity and research questions to students answer. Then he/she observes his/her students and hears their responses. So it is ensured that students have communication, dialogues with their groupmates and/or classmates and guesses about the experiments (Türkmen, 2006). During the Term Introduction phase, students use their experience gained from exploration phase to develop an understanding of the science concept and explain the science concept with guidance from the teacher. The role of teacher is to be mediator in assisting students to formulate these relationships and introduce the scientific term. Crucial thing of this phase is to move reality from inside the experience to the reality of everyday (Cavallo \& Marek, 2003; Eubanks \& Gallaher, 1990; Marek \& Cavallo, 1997; Maier \& Marek, 2006; Türkmen, 2006). Last phase is Concept Application that students apply the science concept on new situations such as additional experiment, reading, film, and discussion. The teacher should make an assessment of the students' abilities and thinking habits in investigating science ideas. The main propose is to connect the newly learned concept to previously learned concept (Cavallo \& Marek, 2003; Köseoğlu \& Tümay, 2010; Maier \& Marek, 2006; Marek \& Cavallo, 1997; Türkmen, 2006). In formal learning this progress should start at preschool time. Besides giving basic information about realization of main fact and event; aim of science teaching before school is to make them to gain the sensual and psycho-motor ability, and try to help them to understand themselves and people around them (Şahin, 1997; Şahin,1998; as cited in Ayvac1, 2010). One of the most important duties of teacher is to prepare a class where possible to joyful learning while learning and applying science far from traditional science learning (Şahin, 1998; Üstünoğlu, 1990; cited in Ayvac1 2010). In this situation, activities done with preschool children give one-to-one experiences and present permanent learning. Researches showed Learning Cycle based lessons are useful to learn science concepts for elementary school students (Marek \& Cavallo, 1995; Ören \& Tezcan, 2008; Renner et al. 1973, cited Lawson, 2001), secondary school students (Dogru-Atay \& Tekkaya, 2008; McComas, 1992; Parker, 2000), high school students (Abraham \& Renner, 1986, cited Lawson, 2001; Cavallo \& Marek, 2003; Lawson, 1996; Patterson \& Merwin, 2002; Renner, Abraham, \& Birnie, 1988, cited Lawson, 2001), and university students (Al khawaldeh, 2013; Ateş, 2005a-b; Hanuscin \& Lee, 2008; Köseoğlu \& Tümay, 2010; Marek, Laubach, \& 
Pedersen, 2003; Nuhoğlu \& Yalçin, 2006), and develop all ages' ability of questioning, searching, solving problems (Settlage, 1999).

The purpose of study is to examine how effective learning cycle model of preschool students learning on growth of plant and their opinions about the lesson due to limited research about preschools students learning via Learning Cycle.

\section{Method}

\section{Research Model}

In this study quantitative research method was used. Data were analyzed by using frequency analysis.

\section{Sampling}

Convenience sampling was used in this study. The study was carried out in İzmir. 25 students aging 6 years attending the preschool in rural area participated in this study.

\section{Data Collection Instruments}

In the study, as the subjects are so young, qualitative data were collected by direct observation, interviewing (asking open-ended questions and filling observation sheet) and drawings.

\section{Data Collection Process}

Data collection process took four weeks. First of all, before intervention learning cycle lesson plan was prepared. Then students were divided into 12 groups and each group has 2 students except one group has 3 students.

In the Exploration Phase (1.5 week):

- Each group is given 2 plastic cups, water, fruit juice, some cotton and some seed of bean or chickpea.

- The 3-4 seeds will be placed on a cotton on the bottom of a plastic cup, A different plastic cup will be used for each treatment, then

- Each cotton will be dampened by the water and fruit juice then to cover the seeds with a piece of cotton, then student's names are written on each cup,

- They will tell to put their cup wherever they want in the classroom (such as near window, out-side door, inside the closet).

- The cottons will be checked daily (except weekends) and moistened as needed.

- Each group will report what they see to teacher.

- During a week, they will ask 3 open-ended questions about pre-knowledge and prediction about the growing seed.

- What's required growing up seeds?

- Why do you think like that?

- What is the name of the process that is used to grow up seeds?

- After a week; all set ups will be brought together and put on a table in the middle of the classroom; then students will be asked;

- Can you please tell me what you see here?

- Are all the set ups on the table are same? 
- What can be the reasons of those differences, in your opinion?

- $\quad$ Each group will try to answer the questions. They will be expected to discuss about their opinions.

In Term Introduction Phase (1 week):

- The following discussion time, each group will give their answers about questions asked in the exploration phase.

- $\quad$ There will be expected to whole class discussion about steps and process to grow up seeds. Because there will be differences between cups, like small grow, big lengths grow and some decay, reasons of these differences will be asked and discussed.

- According to students' answers, it will be indicated that water, temperature, sun light and air are required to grow up a seed (this part is marked with students' own answers). It will be tell that this process is called "germination"

In Concept Application Phase (1.5 week):

- $\quad$ Students are asked questions written below

- Where else can germination be used?

- Why is it needed?

- What else can we germinate?

- Can we germinate carrots in your opinion?

- Then let's will do another experiment with carrot,

- Now I am going to cut the tops of carrots (green part). I will want you to put them in your bowl but the part which has overhang is going to be up. Then, put those set ups wherever you want in the classroom, like we did seed experiment. All responsibilities of these carrots are students. Students are going to observe this study for 10 days. Each day groups will report to teacher. We'll see whether they will germinate as seeds or not.

- After ten days all set ups will be put on the table and discussed whether they will germinate or not. So errors and mislearnings will be found and corrected.

- $\quad$ End of the lesson they are asked questions,

- Could you draw a picture about germination?

- Then will interview with 12 students selected from each group. They will be asked

- How you feel in this whole lesson?

- Would you have this type of lesson for other topics?

\section{Findings}

Firstly, students were asked 3 open-ended questions about what they know growing plant during the exploration phase. As seen in Table 1,50\% of groups told that plants need water, sun and soil to grow up. Water and soil percentage is 33.3, sun and soil percentage is 16.7. When the reason was asked; some examples of students' answers are below,

Student A-1; "My grandfather does like this and told me like this."

Student H-1; "My mother does like this on flowers, because it has to grow" trefoil."

Student C-2;" My grandmother told like this in the field to grow some wheat and

Student L-1; "Last week when I was watching TV I heard something like that from TRT Çocuk cartoon.

According to results, it was observed that students know about growing up a plant but not enough. It is found out that they don't know "germination "term. Only one student answered as "green-up "which is a close term. The common misunderstanding was seen also in the 
study. Sun is not clear answer; it should have been day-light.

Table 1: Groups' answers of open-ended question middle of exploration phase

\begin{tabular}{lllll}
\hline Questions & \multicolumn{2}{l}{ Students' Answers } & Frequency & Percentage \% \\
\hline What's required growing up a & $\bullet$ & Water, Soil & 4 & 33.3 \\
plant? & - & Sun, Soil & 2 & 16.7 \\
& - & Soil, Water, Sun & 6 & 50 \\
Why do you think like that? & - & Parents told that & 7 & 58.3 \\
& $-\quad$ Parents do like that to & 3 & 25 \\
& & plants at their homes & & 16.7 \\
What is the name of the process & - & Heard from TV & 2 & 25 \\
that is used to grow up a plant ?" & - & 3 & 66.7 \\
& - & Go not know & 8 & 8.3 \\
\hline
\end{tabular}

During experimental process, students were asked to prepare an experimental set up and follow their studies during a week. An observation sheet is filled it out in experiment process by researcher (see Table 2 ).

Table 2: Observation of Groups During Experimental Process in the Exploration Phase

\begin{tabular}{|c|c|c|c|}
\hline Groups & Situation & Observed Attitude & Comments \\
\hline $\begin{array}{l}\text { All } \\
\text { groups }\end{array}$ & $\begin{array}{l}\text { Comparing } \\
\text { fruit juice and } \\
\text { water }\end{array}$ & $\begin{array}{l}\text { All groups saw there is } \\
\text { a problem, if it is } \\
\text { compared the using } \\
\text { waters set-ups }\end{array}$ & $\begin{array}{l}\text { Groups A-C-D-E-F: Seeds do not like fruit } \\
\text { juice. } \\
\text { Groups B-G-H-I-J-K-L: Fruit juice is not } \\
\text { useful for seeds to their growth. }\end{array}$ \\
\hline $\begin{array}{l}\text { Groups } \\
\text { A-B-C-D }\end{array}$ & $\begin{array}{l}\text { Near the } \\
\text { window }\end{array}$ & $\begin{array}{l}\text { Seeds cracked and } \\
\text { grown up, even it is the } \\
\text { highest tall }\end{array}$ & $\begin{array}{l}\text { All A-B-C-D groups: Seeds like sun and water. } \\
\text { Sun get them warm. }\end{array}$ \\
\hline $\begin{array}{l}\text { Groups } \\
\text { E-F-G-H }\end{array}$ & $\begin{array}{l}\text { Inside the } \\
\text { closet }\end{array}$ & $\begin{array}{l}\text { Seeds crack and grow } \\
\text { up, then suddenly they } \\
\text { get pale and their tall } \\
\text { are short }\end{array}$ & $\begin{array}{l}\text { A few days everything is nice but then our } \\
\text { little plant decayed. We think seeds get cold } \\
\text { inside the closet and they are in dark. }\end{array}$ \\
\hline $\begin{array}{l}\text { Groups } \\
\text { I-J-K-L }\end{array}$ & $\begin{array}{l}\text { Out-side the } \\
\text { door (in the } \\
\text { school aisle) }\end{array}$ & $\begin{array}{l}\text { Seeds crack and grow } \\
\text { up, but their tall are } \\
\text { not tall as much as near } \\
\text { the window' set-ups }\end{array}$ & $\begin{array}{l}\text { Something went wrong on their study, because } \\
\text { seeds get cold near the door. }\end{array}$ \\
\hline
\end{tabular}

As seen in Table 2, the students did their all responsibilities, observed and compared with other groups experiments. In that process they had some troubles but they overcomed. They tried to find reason and solution when they faced something wrong. They definitely noticed seeds should not be placed in the cold, dark area and only give water. It is enough awareness for 6 years old students to understand germination. This was a clear sign that they questioned and tried to reach a result without scientific terminology and explanations.

During end of exploration phase students were asked 3 open-ended questions related their observations. The results showed that students reached concepts after their studies and they gathered data about the reasons of germination of plants by comparing (see Table 3). 
Table 3: Groups' answers of open-ended question end of exploration phase

\begin{tabular}{|c|c|c|c|}
\hline Questions & Students' Answers & Frequency & Percentage $\%$ \\
\hline $\begin{array}{l}\text { Can you please tell } \\
\text { me what you see } \\
\text { here? }\end{array}$ & $\begin{array}{l}\text { - My wick pea cracked } \\
\text { - } \quad \text { My bean grew up and became green } \\
\text { - } \quad \text { I had a plant }\end{array}$ & $\begin{array}{l}3 \\
4 \\
5\end{array}$ & $\begin{array}{c}25 \\
33.3 \\
41.7\end{array}$ \\
\hline $\begin{array}{l}\text { Are all the set ups } \\
\text { on the table are } \\
\text { same? }\end{array}$ & $\begin{array}{l}\text { - No ; some of them grew up and became green } \\
\text { but some remained same and some rotted }\end{array}$ & 12 & 100 \\
\hline $\begin{array}{l}\text { What can be the } \\
\text { reasons of those } \\
\text { differences, in your } \\
\text { opinion? } \\
\text { (more than one } \\
\text { answers were } \\
\text { given) }\end{array}$ & $\begin{array}{l}\text { - We gave much water then it smelled } \\
\text { - We did not put in front of window so some } \\
\text { - } \text { didn't grow up or a grew up little } \\
\text { - We put little cotton so it didn't hold enough } \\
\text { - It was cold out-side } \\
\text { - It was dark in closet } \\
\text { - Probably we put few lentil } \\
\text { - We gave enough water needed, full cotton and } \\
\text { under sun then we had a plant }\end{array}$ & $\begin{array}{l}3 \\
3 \\
1 \\
4\end{array}$ & $\begin{array}{c}9.1 \\
27.3 \\
9.1 \\
4.6 \\
13.6 \\
13.6 \\
4.6 \\
18.2\end{array}$ \\
\hline
\end{tabular}

According to the data (knowledge) they gathered, students were provided to say what required conditions to grow up a plant. After they compared their data and discussed, they concluded "water, cotton (soil), seed, sun (light-heat) are required". The missing term was "air". The reason is students could not realize why the seeds in cabinet grew up little then decayed. Then teacher explained the importance of air and then said "this process is called "germination".

In concept application phase, when carrot experiment was done, students saw that germination was succeed when set up was put between cotton, a place which gets air and light (near window) and checked then watered according to their needing with the help of data gathered from first experiment.

9 of 12 the set up germinated, the rest didn't (see Figure 1,2):

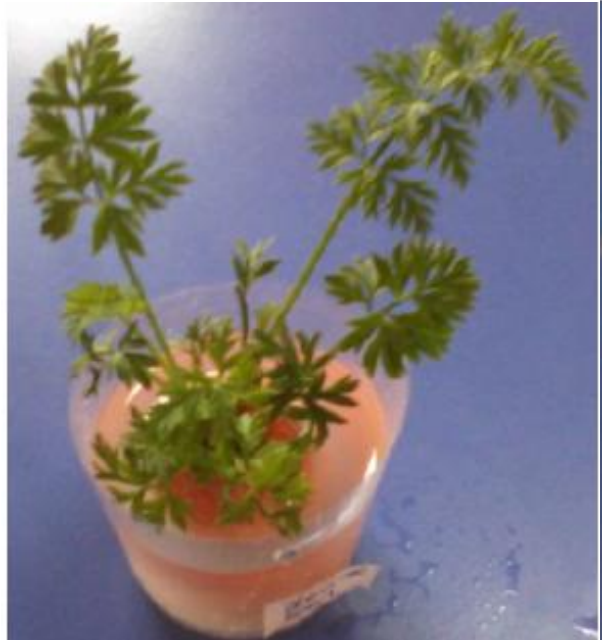

Figure 1: germinated carrot

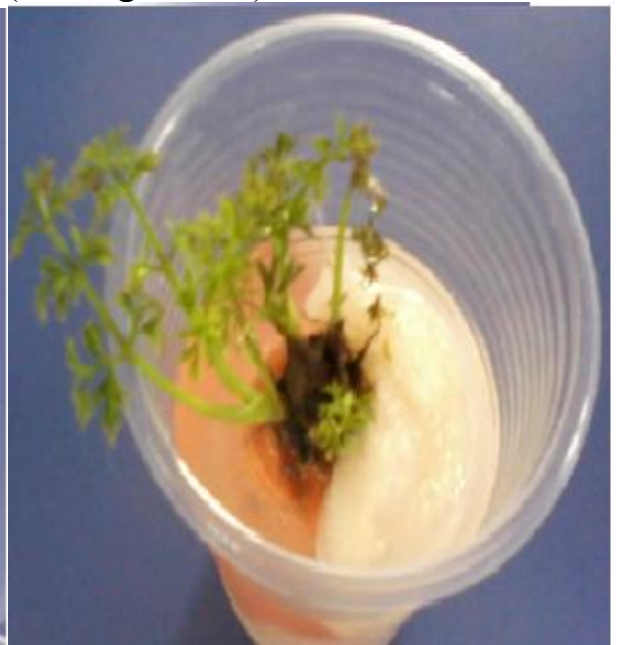

Figure 2: decayed carrot

End of the concept application phase, students were asked same open-ended question like in the term Exploration phase (see Table 4). 
Table 4: Students' answers of open-ended question end of concept application phase

\begin{tabular}{|c|c|c|c|}
\hline Questions & Student's Answers & Frequency & Percentage $\%$ \\
\hline $\begin{array}{l}\text { What's required growing up a } \\
\text { plant? }\end{array}$ & $\begin{array}{ll}\text { - } & \text { Water } \\
\text { - } & \text { Cotton (Soil) } \\
\text { - } & \text { Sun (Light) } \\
\text { - } & \text { Lentil , Chickpea (Seed) } \\
\text { Air }\end{array}$ & $\begin{array}{l}25 \\
19 \\
23 \\
22 \\
18\end{array}$ & $\begin{array}{l}100 \\
76 \\
92 \\
88 \\
72\end{array}$ \\
\hline $\begin{array}{l}\text { What is the name of the } \\
\text { process that is used to grow } \\
\text { up a plant? }\end{array}$ & $\begin{array}{ll}\text { - } & \text { Making germinate or germination } \\
\text { - } & \text { Sodding } \\
\text { - } & \text { Growth }\end{array}$ & $\begin{array}{l}23 \\
1 \\
1\end{array}$ & $\begin{array}{l}92 \\
4 \\
4\end{array}$ \\
\hline
\end{tabular}

Table 4 showed that end of activates done with learning cycle approach students could reach the science by comparing the data gathered from fist hand experience via questioning and discussing. These results also were supported by students' drawings.

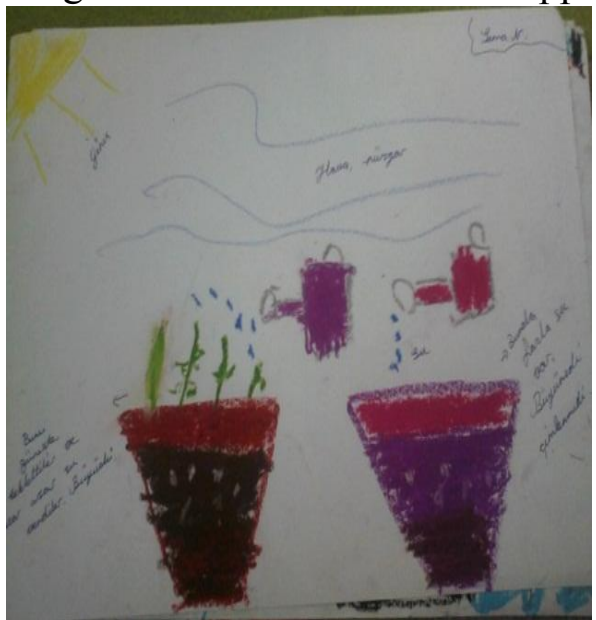

Figure 3: Student's drawing

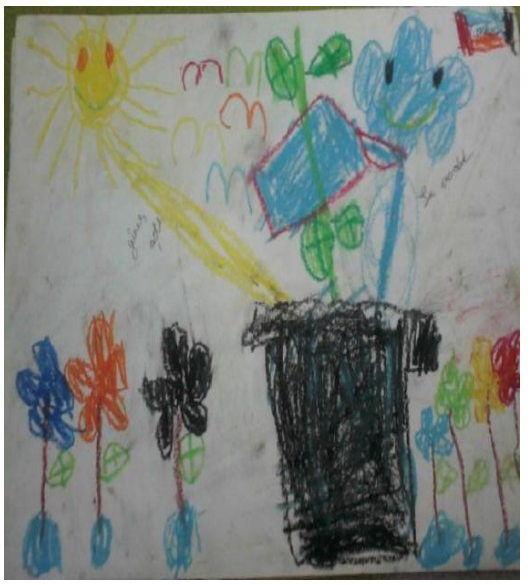

Figure 5: Student's drawing

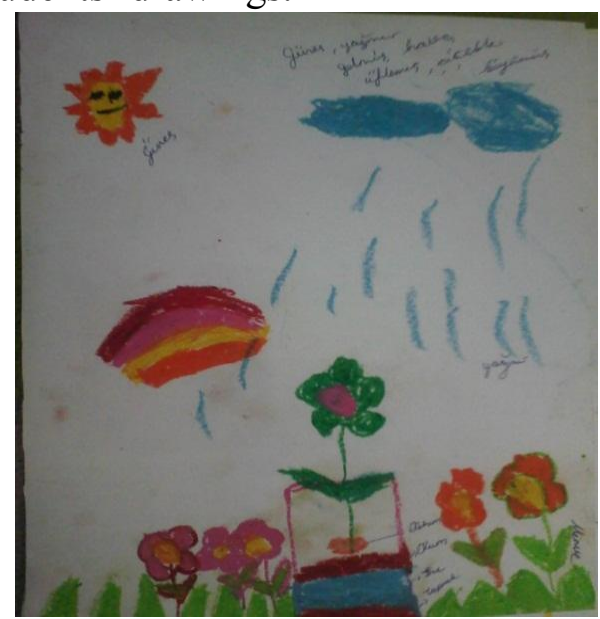

Figure 4: Student's drawing

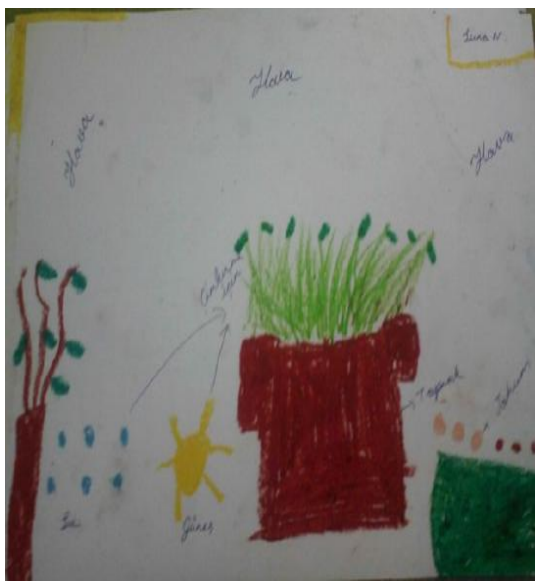

Figure 6: Student's drawing

$80 \%$ of drawings have 3 important terms, sun, water and soil, of germination. That mean 6 years old student understood what seed need to grow up (see Figure 3, 4, 5, 6).

According to interviewed, applying end of the lesson, results ( students gave answers more than one) show that although some students have bad feelings beginning of the lesson, 13 students out of 15 think that they had fun. Another important result is they felt like scientists. Next interview question is also support how useful learning cycle lesson because nobody did not want to be taught via learning cycle, only 2 students could not decide yet (see Table 5). 
Table 5: Students' answers of about lesson

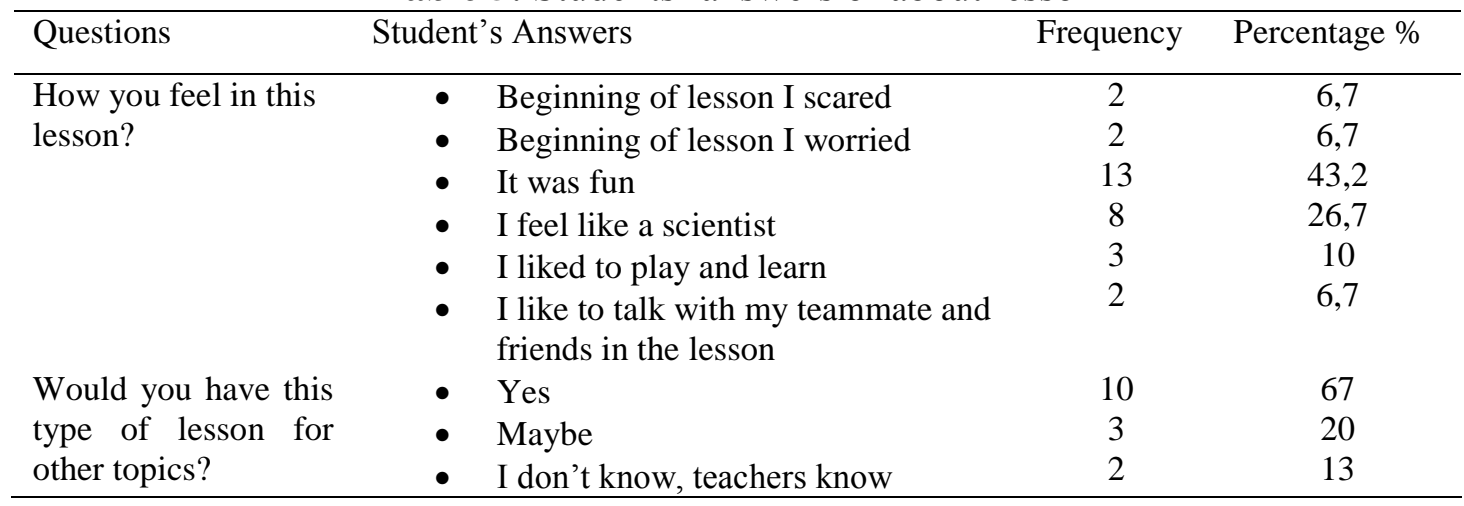

Researcher observation results showed that all the intervention process (using learning cycle lesson plan) students were having fun. They are very young and like to play much thus; if we give them chance to play when we want to teach something, they will have good time and learn. One of the best ways to encourage learning science concepts is using learning cycle approach. They behave like scientist in this study, because they were curious, most of time looked for answers and discussed between us. This learning environment helped them think like a scientist. Given them to search and to be allowed to make their own mistakes and correct them.

\section{Results and Suggestions}

Science and nature activities are very important to help children to acquire the relations between objects and events (Demiriz \& Ulutaş, 2001). A child's attending to science and nature events not only develop cognitive abilities but also help them to develop their motor skills, make easy to learn and acquire ability to approach to the event from scientific aspect (Barnett, 2003; Coolahan et all, 2000; Gürdal et all, 1993; Yaşar, 1993). Learning Cycle is moving from a teacher-initiated model to a student-generated or student-guided model with teacher as facilitator. Learning Cycle can be practiced outdoors, indoors and in a wide variety of content areas. In this study students found out their inadequacy and errors in each step of application and tried to reach the concept by correcting them. End of the lesson it seen students learned the science concept even remembered the concept terminology. In the intervention process students had a great time and gained basic scientific skills, which are questioning, predicting, discussing with groupmates and friends. Although there have not been any study done with this age in Turkey, result overlap with the results of studies had already been done with other ages (Ateş, 2005a-b; Cavallo \& Marek, 2003; Eubanks \& Gallaher, 1990; Köseoğlu \& Tümay, 2010; Maier \& Marek, 2006; Nuhoğlu \& Yalçın, 2006; Ören \& Tezcan, 2008; Settlag, 2000). According to all these data it is clearly observed that science activities based on Learning Cycle are effective on students 'learning and questioning ability. Instead of giving them information from firsthand, information based on their own experience increases their learning, questioning and searching curiosity.

If it is possible to reach those results with that age group, then why not with other age groups. I think it is a great quote from Lawson's "Why this approach?" asked during conference, He said "because it works/ useful" (Marek, 2008). We should try look from our child's perspective to world. As we teacher we can allow our students to learn how to do things for themselves and give them the self-respect and confidence that come with independence. 


\section{References}

Abraham, M. \& Renner, C. (1986). The Sequence of Learning Cycle Activities in High School Chemistry. Journal of Research in Science Teaching, 23(2), 121-143.

Al khawaldeh, S.A. (2013). Prediction/discussion-based learning cycle versus conceptual change text: comparative effects on students' understanding of genetics. Research in Science \& Technological Education, 31(2),168-183

Ateş, S. (2005a). The Effectiveness of the Learning Cycle Method on Teaching DC Circuits to Prospective Female and Male Science Teachers. Research in Science \& Technological Education, 23(2), 213-227.

Ateş, S. (2005b). The Effects of Learning Cycle on College Students' Understandings of Different Aspects in Resistive DC Circuits. Electronic Journal of Science Education, 9(4), 1-20.

Ayas, A. (1995). Fen Bilimlerinde Yeni Program Geliştirme Ve Uygulama Teknikleri: İki Çağdaş Yaklaşımın Değerlendirilmesi [Development of New Curricula and Application Techniques in Science: Evaulation of Two Modern Approaches]. Hacettepe University Journal of Education, 11, 149-155.

Ayvacı, H. Ş. (2010) Okul Öncesi Dönem Çocuklarının Bilimsel Süreç Becerilerini Kullanma Yeterliliklerini Geliştirmeye Yönelik Pilot Bir Çalışma [A Pilot Survey to Improve the Use of Scientific Process Skills of Kindergarten Children], Necatibey Faculty of Education, Electronic Journal of Science and Mathematics Education, 4(2), 1-24.

Barnett, W.S. (2003). Better Teachers, Better Preschools: Student Achievement Linked to Teacher Qualifications. National Institute for Early Education Research, Preschool Policy Matters, Issue 2, 1-12

Büyüköztürk, Ş. (2012). Bilimsel Araştırma Yöntemleri [Scientific Research Methods], Pegem Publishing, Ankara.

Cavallo, A.M.L. \& Marek, E. (2003). Eliciting Students' Understandings of Chemical Reactions Using Two Forms of Essay Questions during a Learning Cycle. International Journal of Science Education, 25(5), 583-603.

Coolahan, K., Fantuzzo, J., Mendez, J., \& McDermott, P. (2000). Preschool peer interactions and readiness to learn: Relationships between classroom peer play and learning behaviors and conduct. Journal of Educational Psychology, 92(3), 458-465.

Demiriz, S. ve Ulutaş, İ. (2001). Okul Öncesi Eğitim Kurumlarındaki Fen ve Doğa Etkinlikleri İle İlgili Uygulamaların Belirlenmesi [Determination of Science and Nature activities and Related Practises in Preschool Education Institutions], IV. Congress of Science Education, Proceeding Book, 89-90.

Dogru-Atay, P \& Tekkaya, C (2008). Promoting Students' Learning in Genetics with the Learning Cycle. The Journal of Experimental Education, 76(3), 259-280

Gürdal, A., Çağlar, A., Şahin, F., Ökçün, F. \& Macaroğlu, E. (1993). Okulöncesi Dönemle İlgili Fen Faaliyetlerine Örnekler [Sample Of Science Activities Relating Preschool Term], 9. Symposium of Ya-Pa Preschool Education and Publishing, Ankara: 164.

Hanuscin, D.L. \& Lee, M.H. (2008). Using the Learning Cycle as a Model for Teaching the Learning Cycle to Preservice Elementary Teachers. Journal of Elementary Science Education, 20(2), 51-66.

Köseoğlu, F. \& Tümay, H. (2010). Temel Kimya Laboratuvarlarında Öğrenme Döngüsü Yönteminin Öğrencilerin Kavramsal Değişim, Tutum ve Algılarına Etkisi [The Effects of Learning Cycle Method in General Chemistry Laboratory on Students' Conceptual Change, Attitude and Perception]. Ahi Evran University Journal of Kırşehir Education Faculty, 11(1), 279-295. 
Lawson, A.E. (1996). Introducing Mendelian Genetics Through a Learning Cycle. The American Biology Teacher, 58, 38-42.

Lawson, A.E. (2001). Using the Learning Cycle to Teach Biology Concepts and Reasoning Patterns. Journal of Biological Education, 35:4, 165-169

Lawson, A.E., Abraham, M. R. \& Renner, J. W. (1989). A Theory of Instruction: Using the Learning Cycle to Teach Science Concepts and Thinking Skills, NARST Monograph 1, Columbus, OH: National Association of Research in Science Teaching, 69-76.

Maier S. J. \& Marek E. A. (2006). The Learning Cycle: A Reintroduction. The Physics Teacher, 44(2), 109-113.

Marek, E. (2008). Why the Learning Cycle? Journal of Elementary Science Education, 20(3), 63-69.

Marek, E. A., \& Cavallo, A. M. (1995). Passkeys to learning science in the elementary schools: The Data and Language of Science. Journal of Elementary Science Education, 7(1), 1-15.

Marek, E.A. \& Cavallo, A. M. L. (1997). The Learning Cycle: Elementary School Science and Beyond. Revised Edition, Heinemann, Portsmounth, NH, USA.

Marek, E. A., Laubach, T. A., \& Pedersen, J. (2003). Preservice elementary school teachers' understandings of theory based science education. Journal of Science Teacher Education, 14(3), 147-159.

Marek, E., Eubanks, C. \& Gallaher, T. (1990). Teachers' Understanding and the Use of the Learning Cycle. Journal of Research in Science Teaching, 27(9), 821-834.

McComas, W. F., III. (1992). The Nature of Exemplary Practice in Secondary School Science Laboratory Instruction: A Case Study Approach (Doctoral dissertation, University of Iowa, 1991). Dissertation Abstracts International, 52(12), 4284A.

Nuhoğlu, H. \& Yalçin, N. (2006). Fizik Laboratuvarı Çalışmalarında “Öğrenme Halkası Modelinin" Öğrenci Başarısına Etkisi The effect of Learning Cycle Models on students' academic succeed in Physics Lab. Activities). Journal of Turkish Science Education, 3(2), 50-65.

Ören F. Ş. \& Tezcan R. (2008). İlköğretim 7. Sınıf Fen Bilgisi Dersinde Öğrenme Halkası Yaklaşımının, Öğrencilerin Başarı ve Mantıksal Düşünme Yetenekleri Üzerine Etkisi [The Effectiveness of The Learning Cycle Approach on Learners' Achievement and Logical Thinking Ability in Seventh Grade Science Classes of Elementary School], Uludag University Faculty of Education Journal, XXI (2), 427-446.

Parker, V. (2000). Effects of a science intervention program on middle-grade student achievement and attitudes. School Science \& Mathematics, 100 (5), 236-243.

Patterson, J. \& Merwin, J. (2002). Teaching Planet Classification Using the Learning Cycle. The Science Teacher, 69 (5), 22-26.

Renner, J.W., Abraham, M.R. \& Birnie, H.H. (1988). The Necessity of Each Phase of the Learning Cycle in Teaching High School Physics. Journal of Research in Science Teaching, 25, 39-58.

Soylu, H. (2004). Fen Öğretimde Yeni Yaklaşımlar [New Approaches in Science Teaching] (1. Ed.), Ankara: Nobel Publishing.

Settlage, J. (2000). Understanding the Learning Cycle: Influences on Abilities to Embrace the Approach by Preservice Elementary School Teachers. Science Teacher Education, 84, 43-50.

Türkmen, H. (2006). How Science Should Be Taught by Using Learning Cycle Approach in Elementary Schools. Elementary Education Online, 5(2), 1-15.

Vernadakis, N., Avgerinos, A., Tsitskari, E. \& Zachopoulou, E. (2005). The Use of Computer Assisted Instruction in Preschool Education: Making Teaching Meaningful. Early Childhood Education Journal, 33(2), 99-104. 
Yaşar, Ş. (1993). Okul Öncesi Ĕ̆itim Öğrencilerinde Fene yönelik Duyuşsal Özellikler [Affective Characteristics for Science in Preschool Students], 9. Symposium of Ya-Pa Preschool Education and Publishing, Ankara: 140-142 